\section{PRIZES PROPOSED BY THE PARIS ACADEMY OF SCIENCES FOR 1909.}

$G E O M E T R Y .-$ The Francœur prize, 1000 francs, is awarded annually for discoveries or work useful to the progress of pure and applied mathematics. For the Bordin prize, 3000 francs, the question proposed is as follows:-The absolute invariant which represents the number of distinct double integrals of the second species of an algebraic surface depends on a relative invariant $\rho$, which plays an important part in the theory of the integrals of total differentials of the third species and in that of algebraic curves traced on the surface. It is proposed to make a profound study of this invariant, and especially to find out how to determine its exact value, at least, for numerous kinds of surfaces.

Mechanics.-A Montyon prize, 700 francs, for inventing or improving instruments useful to the progress of agriculture, the mechanical arts, or sciences. The Poncelet prize will be awarded for a work on applied mathematics. The question for the Vaillant prize, 4000 francs, is to improve in an important point the application of the principles of the dynamics of fluids to the theory of the screw. The Boileau prize, 1300 francs, is for researches on the motion of fluids, sufficient to contribute to the progress of hydraulics.

Navigation.-The Plumey prize is for improvement of steam engines or any other invention which has most contributed to the progress of steam navigation.

Astronomy. - The Lalande prize, 540 francs, is for the most interesting observation, memoir, or work useful to the progress of astronomy, and the Valz prize, 460 francs, is awarded on similar terms. The G. de Pontécoulant prize, 700 francs, is for the encouragement of researches in celestial mechanics.

Geography.-The Tchihatchef prize, 3000 francs, for the recompense or encouragement of young naturalists distinguished in the exploration of the lesser known parts of Asia.

The Gay prize, 1500 francs, for the study of the geographical distribution of one class of cryptogams.

Physics.-The Hébert prize for the author of a treatise or discovery for the application or practical employment of electricity; the Hughes prize, 2500 francs, for a discovery or work contributing to the progress of physics; the Gaston Planté prize, 3000 francs, for the discovery of an invention or important work in the field of electricity; the L. La Caze prize, Io,ooo francs, which cannot be divided, for works or memoirs contributing to the progress of physics.

Chemistry.-The Jecker prize, 10,000 francs, for works contributing to the progress of organic chemistry; the Cahours prize, 3000 francs, for the encouragement of young chemists; the Montyon prize (unhealthy trades), a prize of 2500 francs and a mention of 1500 francs, for the discovery of a means of rendering an art or trade less unhealthy; the L. La Caze prize, ro,00o francs, which may not be divided, for the best work in chemistry.

Mineralogy and Geology.-The grand prize of the physical sciences, 3000 francs. The question proposed for I 909 is the stages of evolution of the most ancient quadrupeds found in France. The Delesse prize, I 400 francs, for a work concerning geology, or, in default, mineralogy.

Botany.-The Desmazières prize, I600 francs, for a work on cryptogams; the Montagne prize, I500 francs, for important work bearing on the anatomy, physiology, development, or description of the lower cryptogams; the de Coincy prize, goo francs, for a work on phanerogams the Thore prize, 200 francs, for a memoir on the cellular cryptogams of Europe.

Anatomy and Zoology.-The Savigny prize, 1500 francs, for the assistance of young travelling zoologists, not receiving Government assistance, who occupy themselves more especially with the invertebrates of Egypt and Syria the Da Gama Machado prize, for the best memoir on the coloured parts of the tegumentary system of animals.

Medicine and Surgery. - The Montyon prize, a prize of 2500 francs, and mentions of 1500 francs, for works or discoveries useful in the art of healing; the Barbier prize, 2000 francs, for a discovery in surgical, medical, or pharmaceutical science, or in botany with relation to medicine; the Breant prize, I0o,00o francs. The capital sum will be awarded under the terms of the legacy to anyone discovering a radical cure for Asiatic cholera, either by a specific medicine or by discovering the causes and indicating an undoubted method of destroying these causes. In default of this, the annual interest will be awarded for a memoir demonstrating in a rigorous manner the presence of materials in the atmosphere playing a part in the production or propagation of epidemic diseases. The Godard prize, Iooo francs, for the best memoir on the anatomy, physiology, or pathology of the genitourinary organs; the Baron Larrey prize, 750 francs, for an army or navy doctor or surgeon for a work treating of military medicine, surgery, or hygiene; the Bellion prize, I400 francs, for work forwarding the progress of medicine; the Mège prize, interest on 10,000 francs.

Physiology.-The Montyon prize, $75^{\circ}$ francs, for work in experimental physiology; the Philipeaux prize, 900 francs, for similar work; the Lallemand prize, I80o francs, for researches on the nervous system. The question proposed for the Pourat prize, Iooo francs, for 1909, is the origin of the anti-ferments.

Statistics.-A Montyon prize, prize 1000 francs and a mention of 500 francs, for work having a bearing on French statistics.

History of Science.-The Binoux prize, 2000 francs, for works on the history of science.

General Prizes.-The Arago, Lavoisier, and Berthelot medals. The Gegner prize, 3800 francs, for researches in the positive sciences; the Lannelongue prize, 2000 francs, for the assistance of the relatives of scientific men; the Trémont prize, I 100 francs. The Wilde prize, one of 4000 francs and two of 2000 francs, for work in astronomy, physics, chemistry, mineralogy, or experimental mechanics the Longchamp prize, 4000 francs, for a work on the diseases of man, animals, and plants, from the special point of view of the introduction of excess of mineral substances as the cause of disease; the Saintour prize, 3000 francs; the Victor Raulin prize, 1500 francs, to facilitate the publication of works relating to geology and palæontology, mineralogy and petrography, meteorology and physics of the globe, the prize for 1909 being limited to mineralogy and petrography ; the prize founded by Mme. la Marquise de Laplace; the Félix Rivot prize, 2500 francs; the Jean Jacques Berger prize, 15,000 francs, for work concerning the City of Paris; the Petit d'Ormoy prize two prizes of ro,0oo francs, one for pure and applied mathematics, and the other for natural science; the Pierson-Perrin prize, 5000 francs, for a physical discovery; the Parkin prize, 3400 francs, for researches on the curative effects of carbon in cholera, different forms of fever, and other diseases, or on the effects of volcanic action on the production of epidemic diseases; the Cuvier prize, I500 francs, for a work on zoological palæontology, comparative anatomy, or zoology.

Of the above, the Lalande, Tchihatchef, La Caze, Delesse, Desmazières, and Wilde prizes, and the Lavoisier medal, are expressly offered without distinction of nationality; the Gaston-Planté, Montagne, and PiersonPerrin prizes are limited to persons of French nationality.

\section{RECENT WORK OF GEOLOGICAL SURVEYS.}

THE Geological Survey of Great Britain has issued its "Summary of Progress for 1906" (1907, price 1s.), from which it is clear that a large part of the work of the staff must always be devoted to the revision of geological details in areas already mapped. This is not work that can be carried out hurriedly, or in response to every change in popular geological opinion; but the real need for re-consideration in accordance with modern discovery is at once apparent from the results recorded on pp. 2 to 5 of the present summary. Geological surveys have an important educational duty in addition to their economic functions, and one can never predict where an accurate knowledge of the earth may not lead to the foundation of an industry, or where an industrial inquiry may not suddenly illumine our relation to this globe on which we have to spend our lives.

It is pleasant to observe (p. 6) that the Geological Survey of Great Britain has been in conference with the Agri- 